\title{
The Comparative Study of Youth-Related Agriculture Initiatives: Optimizing the Role of Indonesian Youth in Improving Food Security
}

\author{
I. Zahara Qurani $^{1, *}$, A. Noyara Rahmasary ${ }^{1}$, and N. Fajri Usman ${ }^{1}$ \\ ${ }^{1}$ Tay Juhana Foundation, Jalan Rawa Bebek Utara No. 26, Jakarta, Indonesia
}

\begin{abstract}
In the near future, the food insecurity risk is escalating if the surging population is not followed by increasing youth farmers while arable land is on a declining trend. Only 4 per cent (less than 3.5 million) youth aged 15-35 work as a farmer in Indonesia since the current general perspective of working in agriculture sector seems unpromising for most youth. This worsens the state of food insecurity unless there is a breakthrough to ignite youth interest. While the proportion of youth population both in rural and urban Indonesia are relatively similar (23 per cent and 25 per cent respectively in 2018), different approaches might be needed. Fortunately, many initiatives have been commenced to appeal to more youth. These approaches allow youth to acquire agriculture skills, from enabling land access to exposing the sector to the digital world. Using the available information acquired from secondary data and interviews, this study aims to identify, compare, and define the most viable approach amongst the existing initiatives, including land access, crop insurance, and incentive for youth farmers in rural area; and mainstreaming digital platform such as peer-to-peer lending, local product promotion, and vertical farming to engage urban youth. Eventually, the recommendation from this study will optimize youth role in improving the state of food security
\end{abstract}

Keywords: youth, initiative, agriculture, food security, Indonesia.

\section{INTRODUCTION}

\subsection{Incongruity in supply and demand sides in the agriculture sector}

The exact problem of this study stems from the difference in the definition of some of the terminologies. The two most important are youth and agriculture. The definition of youth varied from one to another. The United Nations assigns youth in the age group of 15-24 years old while it means men and women aged 12-24 in Taiwan, $15-25$ in Thailand, 15-30 in the Philippines, Kamboja, and Indonesia, 15-34 in Mongolia, 15-40 in Nepal and Myanmar, 9-24 in South Korea, and 0-30 in Japan. Although Indonesia uses the 16-30 age group, some youth-related surveys in Indonesia use 25-34 for their studies [1]. There is also a fundamental problem of defining the terminology of agriculture. The broadly understood agriculture makes people often associate the word with working in field farmer only, when in fact there are many relevant occupations such as agricultural engineer, food scientist, agronomist, conservation planner, or water management specialist. This study wants to promote the broad definition of agriculture: the science, art, or practice of cultivating the soil, producing crops, raising livestock and in varying degrees of the preparation and marketing of the resulting products [2].

Due to the present perspective of agriculture, it is therefore not surprising when the number of youth who work in this sector is generally low everywhere. According to Inter-Census Agricultural Survey, there was only 4.5 per cent (less than 3 million out of 64 million) youth aged $<25-34$ working as a farmer in Indonesia [3]. In 2015, Koalisi Rakyat untuk Kedaulatan Pangan (KRKP) studied farmer households in Tegal, Kediri, Karawang, and Bogor and obtained findings that there was only 37 per cent of horticulture farmers' children who want to continue their parents' occupation. The number is higher amongst rice farmers' households, where 54 per cent of the children still want to be a farmer [4]. In another study, the findings show that the land tenure becomes a vital enabling factor that affects the youth preference in working in agriculture sector, especially those who live in rural areas [5].

The pressure also comes from the increasing demand for food production. One way to understand the balance of food supply and demand of a country is by looking at its state of food security. Based on The Economist's Global Food Security Index (GFSI) [6], Indonesia is currently ranked 65 out of 113 countries. Compared to 2017, Indonesia's average score (54.8) is improved. However, the import rate for the same year is increasing compared to the previous one. This will be even more difficult to be fulfilled in 2050 when the global population reaching 10 billion. It is estimated that we need to produce 75 per cent more of today's food to fulfil the 2050's need.

*Corresponding author: zara@tayjuhanafoundation.com 
Unfortunately, the challenge to produce more food is exacerbated by significant pressure from the diminishing area of arable land. Globally, there is a decreasing availability of arable land per person. On average, arable land per person is shrinking from 0.38 ha in 1970 to 0.23 ha in 2000 , with a projected decline up to 0.15 ha per person by 2050 . In Indonesia, where the ratio of land and people has a larger gap compared to other countries, the number is even lower. It was 0.2 hectares per person in 1961, and it decreased to 0.09 hectare per person in 2016 [7].

In summary, this paper identified three main challenges: lack of youth interest, increasing food demand and diminishing arable land over the years. These three intertwined pressures pose threats to the state of food security of one's region. As mentioned before, the lack of available land reduces youth's ability to attain food security through agricultural production. Their food security and livelihood largely depend on agricultural production and land rights.

\subsection{The rise of youth-related initiatives}

Although it is implied that the level youth participation in agriculture is very low, there is a rising trend of initiatives which offers diverse ways for youth to be involved in agriculture sector [5]. One way is through the utilization of the digital platform. There are platforms such as Tanifund and CROWDE that provide ways to invest in farmers; Tanihub, Desa Apps, and Petani Muda that offer more comprehensive services that enable farmers to update their knowledge and initiate partnerships. Other society movements such as the International Association of Students in Agricultural and Related Sciences (IAAS) and Indonesia Berkebun aim to improve the public understanding and experience on agriculture [8-14].

Meanwhile, the government's initiatives focus on improving access to agriculture resource and capital through their programs. Reforma Agraria program focuses on supporting the people to get land certificate while Politeknik Pembangunan Pertanian (Polbangtan) and Penumbuhan Wirausahawan Muda Pertanian (PWMP) aspire to provide youth with quality higher education that promotes the agriculture sector [15-17]. Through Gerakan Pemuda Tani Indonesia (Gempita)'s program, the government directs youth farmers to have access to farming machinery [18].

Consequently, there is now a new generation of young professionals that have the ideas and aspire to become successful entrepreneurs, farmers, tech-savvy experts, researchers, and policymakers. It has not yet been optimized since they are often held back by the outdated yet widely-accepted perspectives that agriculture is not seen as a profitable career with difficulty accessing suitable land; and low market price. Increasing youth ability to produce food on their own may strengthen food security among youth. Unfortunately, it is always a challenge for them to have access to own or manage agriculture lands. The fact that there is a disconnection between education and practice and the exclusion of youth from decision making is also hampering the rise of youth involvement in agriculture sector [19].

\subsection{Identifying gaps and formulating research objective}

At a glance, the challenges described above can be solved with the existing opportunity to improve youth's participation in agriculture sector. However, the effect of those initiatives is not yet measurable. To effectively address the challenge of youth in agriculture, one should understand the main factors that limit the number of youth involvement in agriculture. Globally, some studies aim to analyze this background. Leavy and Hossain [20] described that the low level of youth participation in agriculture, particularly in developing countries, does not always stem from lack of interest but the limited availability of land and capital. This also applies in Indonesia which is included as one of the case studies in the particular research. Likewise, the existing local researches and studies also show similar results which highlight the need to provide access to agricultural capitals. Based on KRKP study [4], family support, both moral and materials becomes a vital factor in farmer households so that their children can continue working as farmers.

From this plethora of study, the scope of research unfortunately only covered youth interest to become field farmers. Very limited studies found in assessing youth interest to work in the broader term of the agriculture sector. Susilowati [21] discussed the importance of introducing the youth to broader coverage of agriculture sector, for example, to promote the opportunities offered by off-farm (post-harvest) agriculture. A study by Ambarwati [5] mentioned the increasing efforts to introduce youth to modern agriculture that not only focus on the field (on-farm agriculture). This includes the potential roles of institutions and organizations in accommodating youth interest in the introduced broader definition of agriculture.

Therefore, this study wants to add values and deepen understanding of the existing discourse about the pathway to promote broader and modern agriculture to youth, which eventually strengthens the state of food security. This study compares and measures the impacts of programs' implementation of several youth-related initiatives in Indonesia that focuses on accelerating youth participation in the agriculture sector. The word 'initiative' was selected instead of 'institution,' 'organization,' 'community' to cover more grounds so that the study is more inclusive.

\section{METHODOLOGY}

The nature of this study is preliminary and is intended to serve as descriptive research. Therefore desk research is mainly utilized throughout the study to collect, describe, 
and measure the data and information relevant to existing and relevant initiatives. After the data collection process, this study uses two main approaches to obtain the results, namely: stakeholder analysis and comparative analysis.

\subsection{Stakeholder mapping}

As the first step of data processing, stakeholder mapping was principally conducted to identify, differentiate, and categorize, as well as investigate the links between relevant stakeholders [22]. This study mostly based on the analysis of literature review found on the internet. The name of initiatives was collected, along with the respective description, origin, value, and program. This study used a purposive sampling where we had originally aimed to collect initiatives with specific features: program, organization, initiative, community, government, agriculture, farmer, and youth. The combination of the aforementioned keywords, in Indonesian language version, were input to the online search engine. The search result were then analysed to match the purpose of the research. In total, twenty three youth-related initiatives were selected.
In differentiating and categorizing the stakeholders along with understanding the map of the stakeholders, this study used a similar approach as Sinha [23] who categorized the stakeholders into continuum level and plotted them into a matrix. In doing so, the participation and the effect of the plotted initiatives can be understood.

Sinha [23] uses the matrix of interest-influence and has four categories of victims, bystanders, stakeholders who can make differences, and stakeholders who need to be made more responsible. Meanwhile, this study uses the matrix of the used approaches and the main organizers. The selection of these two axes was decided based on the process of comparing and contrasting the selected initiatives. As a result, the similarities and differences of one initiative to others were found to be the platform it used to conduct their program and the initiator as well as the daily organizer of the initiative. As can be seen in Figure 1, a matrix for stakeholder analysis was formulated with the $\mathrm{x}$-axis of used approaches, i.e., conventional (left), digital (right) and the y-axis of main organizers, i.e., government (top), community (bottom).

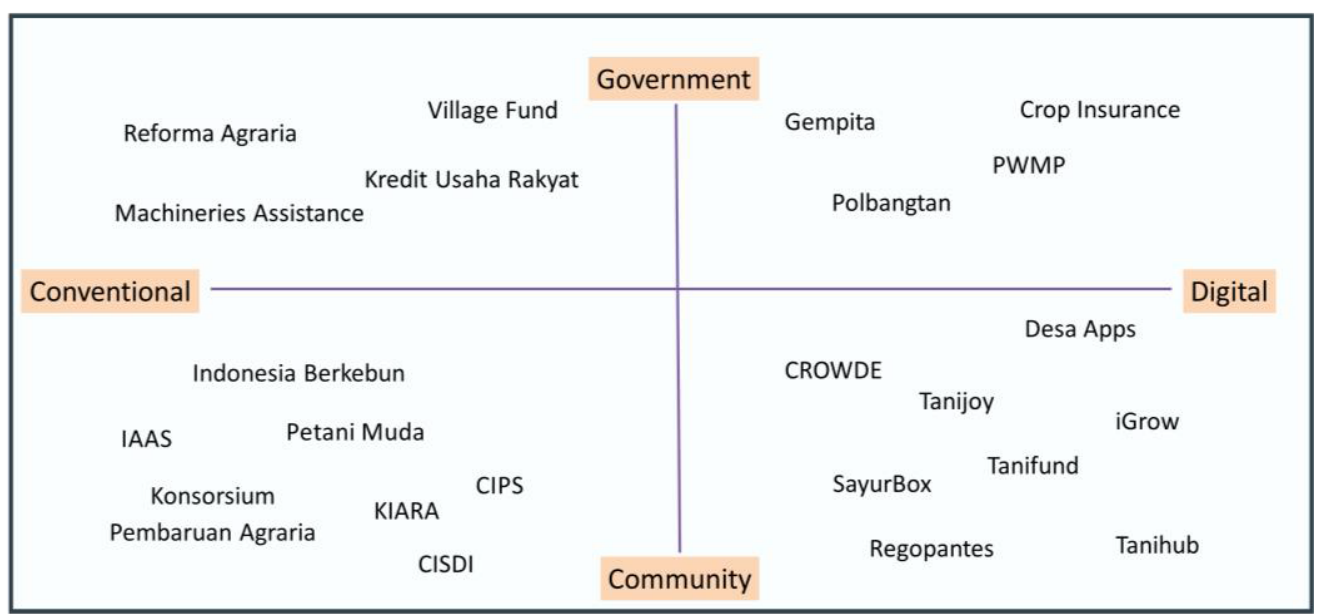

Figure 1. Stakeholder matrix of the twenty-three youth-related initiatives on the agriculture sector.

\subsection{Comparative analysis}

As stated in the objective, this study eventually wants to measure the impact of each initiative in relation to the improvement of food security. Instead of using fulldescriptive approach to inform the result, this study chose to score each of the initiatives on the selected parameter. Expectedly, this can provide a more nuanced indication for the targeted stakeholders in formulating the direction for the improvement [24].

The selected parameters for this comparative analysis was derived from food security dimensions in accord with the Food and Agriculture Organization (FAO). Using the definition of food security stipulated during World Food Summit in 1996, FAO defined that "Food security exists when all people, at all times, have physical and economic access to sufficient safe and nutritious food that meets their dietary needs and food preferences for an active and healthy life [25]." The four main dimensions are:
1. Availability: Principally, this dimension means the physical availability of the food. It mainly refers to the "supply-side" of food security and can be measured from the level of food production, stock levels, and net trade.

2. Accessibility: Sufficient supply of food is not a guarantee of food security unless the people have economic and physical access to the food. It is therefore vital to pay attention to a greater policy focus on incomes, expenditure, markets, and prices.

3. Utilization: The main emphasize of food utilization is how people can get adequate energy and nutrient intake as the result of good care and feeding practices, food preparation, diversity of the diet and intra-household distribution of food.

4. Stability: The last dimension signifies a stable state of the other three dimensions over time. Some factors may hamper the state of food security, such as adverse weather conditions, political instability, and economic factors (unemployment, rising food prices). 


\section{RESULTS}

\subsection{The relevance map of existing stakeholders among youth-related initiatives}

To have a definite boundary, the features of the initiatives included in this study are those initiated by youth and/or aimed for youth. It is principally all the initiatives which have programs or part of its programs aimed to improve youth participation in the agriculture sector.

Using the determined $\mathrm{x}$ and $\mathrm{y}$-axis, four stakeholder categories were formed (Figure 1). The initiatives in the top-left quadrant are those who are organized largely by the government using conventional approaches. Reforma Agraria, Village Fund, Machineries Assistance, and Kredit Usaha Rakyat belong to this group. These initiatives target the smallholder farmers who work on field in rural and periurban agricultural area as their main audience. The offered products and services are also aimed to support the primary needs to do farming. The ones in the topright quadrant are also connected to the government with a more digitalized aspect in its program implementation. The initiatives in this quadrant are not only targeting those who work on field - such as Gempita and Crop Insurance - but also targeting youth who have not yet involved but have interest in agriculture sector - such as Polbangtan and PWMP. Therefore, digital platforms accomadate wider dissemination of their objectives.

Meanwhile, the initiatives in the bottom-left quadrant are those initiated and managed independently by individuals or groups of civilians with their programs which lean toward conventional approaches. Similar to the in top-right quadrant, the initiatives such as Indonesia Berkebun, IAAS, Petani Muda, Konsorsium Pembaruan Agraria, KIARA, CIPS, and CISDI not only target those who already work in agriculture sector. Each of the initiative has more specific objective in the context of promoting agriculture. For example, Indonesia Berkebun wants to expose agriculture practice in the urban area, CIPS advocates the right to eat affordably, and CISDI promotes the local crop as alternative nutrient in areas where food access are limited. In practice, their approach were interactive and proactive with direct involvement of the target audience through various projects.

Lastly, the initiatives in the bottom-right quadrant are driven by the communities who utilize digital platforms in their programs' implementation. CROWDE, Desa Apps, Tanijoy, Tanihub, Tanifund, iGrow, SayurBox, and Regopantes. In this quadrant, all of the initiatives use mainly mobile application as the tool to carry out their mission. Desa Apps and Tanihub provide knowledge management platform for farmers, Sayurbox and Regopantes connect farmers and their buyers directly to optimize the supply chain, while CROWDE, Tanijoy, Tanifund, and iGrow accommodate more people to be involved in agriculture sector by investing in farming activities.

Based on the mapping, some findings can be derived. On one hand, there is no specific differentiation between the initiatives which rely more on conventional approach and those who use various digital tools. On the other hand, there is distinct features which differ intiatives affiliated to the government and to the community. Initiatives by the government centralize the effort to boost the basic activities of agriculture, i.e. onfield agriculture. Meanwhile, initiatives by the community are more general in context of agriculture sector (i.e. include off-field agriculture), yet also more diverse since the scope of each initiative is specified.

\subsection{Comparison result: The not-so-diverse foci of the selected initiatives}

Based on the four groups resulted from the stakeholder analysis, this study selected two of each group as case study representatives. The selection was based on the abundance of available data and information relevant to the initiatives. Table 1 shows the result of the comparative analysis of the selected initiatives.

Table 1. The result of comparative analysis on eight selected initiatives. The fourth dimension (stability) was omitted since none of the selected initiatives comprehensively covers the other three dimensions.

\begin{tabular}{|c|c|c|c|c|}
\hline & Initiative & Availability & Accessibility & Utilization \\
\hline \multirow{2}{*}{$\begin{array}{l}\text { Government- } \\
\text { Conventional }\end{array}$} & Reforma Agraria & 0 & + & 0 \\
\hline & Village Fund & + & + & 0 \\
\hline \multirow{2}{*}{ Government-Digital } & Crop Insurance & + & + & 0 \\
\hline & Polbangtan & 0 & + & 0 \\
\hline \multirow{2}{*}{$\begin{array}{l}\text { Community- } \\
\text { Conventional }\end{array}$} & $\begin{array}{c}\text { Konsorsium Pembaruan } \\
\text { Agraria } \\
\end{array}$ & 0 & + & 0 \\
\hline & CISDI & 0 & + & + \\
\hline \multirow{2}{*}{ Community-Digital } & Tani Group & 0 & + & 0 \\
\hline & Desa Apps & + & 0 & + \\
\hline
\end{tabular}

Each of the initiatives was labelled as $(+)$ 'covered' and scored $(+)$ if the initiative concerns and/or works in that particular dimension. Otherwise, the initiative was labelled 'not covered' and scored $(0)$. 
Since 2015, Dana Desa or Village Fund is essentially provided to the villages so that they can optimize its potentials in order to improve the economic aspect and eventually the local welfare. Regarding this study, the highlight of the fund utilization is to accommodate people's access to public facilities such as groundwater well, drainage or irrigation network, and reservoir [26]. In the long run, the infrastructure availability is expected to attract youth interest to stay and advance the local agriculture sector, not only in field practice but also in devising an integrated system that covers upstream to downstream process [27]. Besides, the village fund can also be allocated for training programs such as workshops on farming and fishery business development [26]. The improvement of agricultural infrastructure has been said to support the farmer in maximizing their productivity. Nationally, rural per capita income has increased from Rp572.586 in 2013 to Rp804.011 in 2018 [28].

Reforma Agraria - a Nationally Prioritized Program (Program Prioritas Nasional) - comes with three main programs including asset legalization, land redistribution, and social forestry. In particular with asset legalization, it increases people's access to agricultural capital. In 2018, the Ministry of Agrarian and Spatial had conducted land consolidation for the development of techno-science-based farming from 510 hectares exHGU (hak guna usaha or the right of exploitation) land in Soppeng, South Sulawesi [15]. A presidential decree was issued for 8900 households in Cianjur to have rights in utilizing 1.5 hectares each of land under social forestry for 35 years [29].

Also in 2015, the Ministry of Agriculture, in collaboration with PT Asuransi Jasa Indonesia (Jasindo) released a crop insurance program with the main objective to protect smallholder farmers in the event of crop failure. Farmers only need to pay the insurance premium of $\mathrm{Rp} 36.000$ per hectare from the total of Rp180.000 since the rest of the premium is paid by the government. Nevertheless, the program's achievement until the third quartile of 2017 was still far from the target [30]. In early 2019, the crop insurance program is available to be used via a mobile application and is complemented by climate news of specific regions [31].

In term of education, the Ministry of Agriculture introduced Polbangtan in several cities of Indonesia. Polbangtan is a form of a vocational higher education institution that strives to regenerate skilled workforces in the agriculture sector, especially to promote the agents of change in socioagripreneur. In its implementation, Polbangtan has partnerships with 29 universities and private entities to aid the youth in entrepreneurial agriculture program (PWMP) [16,17].

Meanwhile, grass-roots initiatives have a broader range of programs with concerns ranging from agricultural education, practical guidance, to farmers' advocacy. The Consortium of Agrarian Reform or Konsorsium Pembaruan Agraria (KPA) aims to actualize fair agrarian system and guarantee the equality for the allocation, possession, and cultivation of agrarian source that leads to the prosperity of the underprivileged. While the government's Reforma Agraria started its programs in 2018, KPA has been on the battle to improve the state of farmer's since 1995. The main programs of KPA consist of policy advocacy, campaign, and organization strengthening, all to empower the people to have better access to agricultural capital [32]. Similarly, the Center for Indonesia's Strategic Development Initiatives (CISDI) has a program called Pencerah Nusantara that revolves around the public health sector [33]. It is therefore important for the program to have training on fitting utilization of especially local food.

Other community-based movements such as Tani Group and Desa Apps address the food security dimensions using a more modern approach (i.e., mobile application). Tani Group has two main subsidiaries namely Tanihub and Tanifund which collectively aim to empower farmers by providing access to market and financial support in an effort to accelerate the positive impact of agriculture sector [8,10]. Their programs mainly take the form of supporting and guiding the farmers to have added-value to their commodities and at the same time connecting the farmers to the end-users. A farmer group called Pangudi Boga in Blora (Central Java) experienced that their partnership allows them to market their products to a wider range of consumers while more competitive profit can be obtained and the farmers' knowledge on the post-harvest process can be improved. As for Desa Apps, its developer from Gadjah Mada University (UGM) focuses on providing knowledge and guidance for farmers and those who are interested in agriculture. Various information is available in its main features where users can discuss with experts and practitioners under different themes from weather and climate effects, commodity price, to market state [11].

The findings show that most of the existing initiatives focus on accessibility, especially on land and financial accesses. Meanwhile, the food security pillar of utilization has the least coverage. On the fourth food security dimension, i.e., stability, this study found that none of the initiatives explicitly are addressing the challenge. In Indonesia, the role of ensuring the stability of the three dimensions is largely posed by the government, especially on the national level.

\section{DISCUSSION}

\subsection{The performance of the used approach}

The limited exposure on each of the initiatives has affected the accuracy of this study since it is solely based on desk research. Nevertheless, the approach was still chosen to understand the nature of the existing initiatives. Using this method, this study is able to understand the progress of the online discourse on youth and agriculture. It is safe to assume that this particular discourse still has a niche among particular groups who are already exposed to the relevant ideas previously.

As mentioned before, the nature of this study is preliminary. Therefore, the follow-up studies are expected to have more inputs in analyzing the 
stakeholder, for instance by conducting interviews and discussions for better comprehension of the stakeholder map [22]. Validation is also needed by contacting each of the initiatives and confirming their progress on the program implementation via field observation. It is therefore has been the intention of the author to construct this study as a preliminary one. The findings will be used to approach the selected initiative and engage further.

\subsection{Different approaches for different cohorts of youth}

Correlating the literature and the findings of this study, the view on perceiving youth as one homogenous group became obsolete. Instead, there should be examinations of specific cohorts of the youth since they vary across regions and thus face different barriers on life [34]. Based on the result, this study deduces that the available range of approaches used by the existing initiatives can be assigned into two categories: urban youth approach and rural youth outlook. For urban youth, the highlights are in mainstreaming digital platform to accommodate better peer-to-peer (P2P) lending and local product promotion. Meanwhile, the fitting focus for rural youth would be on enabling agricultural capitals such as land access, crop insurance, and incentive for youth farmers.

These approaches agree with the GFSI findings in the perspective of strengthening the state of food security. Indonesia's weak points are limited public expenditure on agricultural research and development (R\&D), corruption, farmer's lack of access to finance, low protein quality as micronutrient availability, as well as lack of diet diversification. Some of these mentioned challenges to achieve an enabling environment are indeed addressed in the proposed approaches. However, there is still very limited initiatives that focus on the weakest links, i.e., 'utilization' dimension.

\subsubsection{For urban youth}

In the age of rapid growth on the use of information from communication technologies and the spread of globalized culture [35], it is expected that youth aspiration is to stay close to the centre of civilization (i.e., cities). With relatively easy access to the available resources, agriculture can also be managed in urban areas. At least two types of modern agriculture are 'born' in cities: organic farming and urban farming. The demand for organic products was originated from people in cities with relatively higher education while urban farming became popular as one of the alternatives to improve one's food resilience [5]. However, to date, the implementation of these practices are still fragmented.

Another approach for urban youth still utilizes the results of modernization, i.e., digital and internet platforms. As one of the products of digital and internet development, the use of financial technology (fin-tech) rises over the years, including in Indonesia (Figure 2). According to the Financial Services Authority (Otoritas Jasa Keuangan, OJK) report, the characteristic of both fin-tech lenders and borrowers are dominated by those aged between 19-34 years old. In June 2019, the total investment is recorded at Rp44.806.000.000 with 70 per cent of the investors and borrowers are youth (19-34) [36].

456.352 Lenders

162.400 Lenders

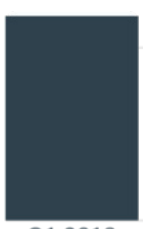

Q1 2018

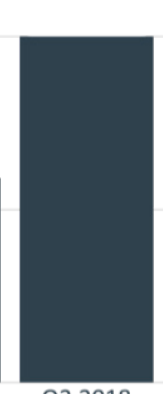

Q2 2018

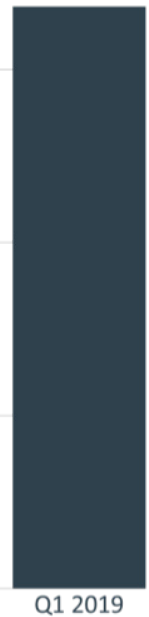

Q1 2019
Figure 2. Number of P2P lenders during January 2018April 2019. Source: [36].

Among a variety of fin-tech, peer-to-peer lending or $\mathrm{P} 2 \mathrm{P}$ has the warmest welcome in Indonesia. Compared to other practices of loan, P2P is more attractive since lenders can earn higher returns while borrowers can borrow money at a lower interest rate. Indonesia's financial regulators even see P2P as the fitting aid for cash-strapped businesses and consumers. In January 2018, around 30 P2P firms extended Rp2.6 trillion from their lenders to borrowers [37]. Leveraging this trend, OJK also wants to promote $\mathrm{P} 2 \mathrm{P}$ practice in the agriculture sector. While initiatives such as CROWDE, Tanijoy, Tanifund, and iGrow formulate their platforms with a focus on supporting farmers, there are also general P2P firms who want to expand into agriculture sector. From this perspective, the future of agriculture largely rests in the hand of youth who are tech-savvy.

\subsubsection{For rural youth}

Enabling better life for rural youth farmers is a multidimension task with many approaches to be utilized. A closer look at the life of rural youth reveals complex stories behind their views and hopes on agriculture. Generally, there was a mismatch in the capacity and interest of rural youth. The ones who could become farmers (i.e., those from wealthy land-owning households) often choose to pursue salaried jobs or wait to inherit the land and end up renting it. Meanwhile, the ones who would become farmers usually comes from landless households [5]. It is difficult for rural youth to be involved in farming without land access, that often comes from family support $[5,21,35,38,39]$. Therefore, the proposed approach for rural youth should first and foremost be on enabling access to land.

The provision of land access needs to be followed by proper mechanization and technology [38]. The Government of Indonesia has initiated programs on 
providing this needs where Gempita even specifically intends their objective to provide machineries for young farmers. It needs to be highlighted that the introduction of mechanization in rural agriculture should be done over times and closely supervised so that it would not harm the local rural farmer. Concurrently, integrating the use of the digital platform in rural agriculture could be the most appropriate opportunities since the use of mobile phones and the internet network have been partial to rural youth life in recent years [5]. Initiatives such as Desa Apps and Tanihub provides knowledge and discussion platform on good agriculture practice. Connecting the rural youth farmer with correct platforms - P2P firms such as Tanifund and CROWDE, next to crop insurance providers - could enhance their access to agricultural capital. Access to financial aids such as loans, incentives, and crop insurance will help rural youth farmer to obtain land tenure.

Furthermore, rural youth needs the knowledge of financial management to be more aware of fair pricing of the marketed commodity. At once, the government has also started to make efforts in conducting programs to transfer agricultural knowledge, upgrade technological skill to access broader markets and expand the entrepreneurship spirits [39]. This can be seen from the program implementation of Polbangtan, PWMP, and Village Fund. Additionally, several nongovernmental initiatives has also contributing to this end. For example, IAAS facilitates students to have real life impact by implementing agriculture project in various rural and peri-urban areas.

\subsection{Promoting rural development to mainstream better images of being a farmer}

While it is pivotal to improve the efforts to appeal youth toward agriculture sector, more attention needs to be given to the underlying cause, that is to empower the area where agricultural lands are mostly located, i.e. rural areas. Many studies have revealed that leaving the villages to pursue a big-city dream is still very attractive for rural youth. This setting is reinforced by the portrayal of rural life by mainstream media which has always been generally accepted as common view. Over the years, urbanization is happening largely due to economic reason as the rural families see viable option out of poverty in urban areas. This fact highlights the significance of promoting rural development to change the course of a country [40].

Besides the needed economic power (i.e., access to land and other agricultural capital), some studies recognize sociological aspects such as status aspiration and merit actually drive some of the rural youth to move to urban areas [35,41]. Setiawan [41] highlights that the decision is affected by individual motivation as well as economic and educational backgrounds. In addition, the decision to move to cities is not permanent. Some of them apparently move back to their villages when they have enough financial aid to access lands [5].

In reality, the villages are now modernized with adequate digital and internet coverage and motorcycles crowding the roads that connect different points in the village [5]. The Indonesian government also has been adjusting its focus to accelerate the progress of rural development. Such a comprehensive development will not only empower rural people to engage in a profitable and sustained manner of agriculture sector but will also eradicate poverty, curb conflict, and make urbanization as a matter of choice instead of desperation [40]. One way to actualize the effort is by empowering agroindustry in villages with an integrated upstreamdownstream agriculture practice. The various on-farm and off-farm activities will boost the added values, diversify the rural products, and accelerate the rural capital. To this end, the Village Fund could be used to inaugurate the seeds of agroindustry. However, without help from the other stakeholders, the village officials sometimes experience difficulties in managing such a large amount of fund allocation [42]. In the end, a radical transformation is necessary to allow more rural people to participate in the growth $[35,40]$.

Lastly, using the same optimistic view on rural development, sharing success stories can be used to improve the images of farmers and encourage the youth to be involved in agriculture. Social media should be leveraged to spread positive messages as well as available opportunities, ideas, and networks [38].

\section{CONCLUSION}

Even today, the lack of youth interest, increasing food demand, and diminishing arable land are intertwined and pose threats to the state of food security. A promising opportunity comes from the rise of initiatives that offers diverse ways for youth to be involved in the agriculture sector. The offered ways span from utilizing digital platforms to invest in farmers, disseminating knowledge, and promoting a better image of agriculture; to improving access to agriculture resources and capitals. Although the program implementation of the existing initiatives has been carried out for the past years, unfortunately, the impacts are not yet measurable. This study categorizes the relevant initiatives and scores their program implementation in accord to food security dimensions. The findings show that most of the initiatives are still focused on 'availability' and 'accessibility' dimensions. Meanwhile, 'stability' dimension is still largely governed by the government. This study also finds that specifying approach for different cohort of youth is necessary to optimize and achieve the intended result. While promoting P2P lending is very attractive for urban youth, the approaches for rural youth are more diverse yet essentially needed to enable them to access agriculture resources and capitals. In a bigger picture, rural development should also be promoted to improve the image of being farmers.

\section{REFERENCES}

1. S.H. Susilowati, Forum Penelitian Agro Ekonomi 34(2): 103-123 (2016) 
2. Merriam-Webster, https://www.merriamwebster.com/dictionary/agriculture (no year)

3. Badan Pusat Statistik, HASIL SURVEI PERTANIAN ANTAR SENSUS (SUTAS) https://www.bps.go.id/publication/2019/01/02/c7cb1 c0a1db444e2cc726708/hasil-survei-pertanian-antarsensus--sutas--2018.html (2018)

4. S. Wiyono, Regenerasi Petani https://images.agriprofocus.n1/upload/2015_KRKP_Laporan_Kajian_R egenerasi_Petani1466659556.pdf (2015)

5. A. Ambarwati, I. Sadoko, C. Chazali, B. White, Jurnal Analisis Sosial 20(1\&2) Special Edition (2016)

6. The Economist Intelligence Unit, Global Food Security Index Indonesia https://foodsecurityindex.eiu.com/Country/Details\#I ndonesia (2018)

7. The Worldbank, Arable land https://data.worldbank.org/indicator/AG.LND.ARB L.HA.PC?locations=ID (no year)

8. Tanifund, https://tanifund.com/ (no year)

9. CROWDE, https://crowde.co/ (no year)

10. Tanihub, https://tanihub.com/ (no year)

11. Desa Apps, https://desa-apps.ugm.ac.id/ (no year)

12. Petani Muda, https://petanimuda.org/ (no year)

13. International Association of Students in Agricultural and Related Sciences, https://iaasworld.org/ (no year)

14. Indonesia Berkebun, https://indonesiaberkebun.org/ (no year)

15. Kementerian Komunikasi dan Informatika Republik Indonesia, Reforma Agraria Menjamin Pemerataan Sosial Ekonomi Masyarakat Secara Menyeluruh https://kominfo.go.id/index.php/content/detail/1368 8/reforma-agraria-menjamin-pemerataan-sosialekonomi-masyarakat-secaramenyeluruh/0/artikel_gpr (2018)

16. Kementerian Pertanian Republik Indonesia, Polbangtan Diluncurkan, Kementan Siap Cetak Wirausaha Muda Pertanian

https://www.pertanian.go.id/home/?show=news\&act $=$ view \&id=3379 (2018)

17. Badan Penyuluhan dan Pengembangan SDM Pertanian, Wirausaha Muda Pertanian http://bppsdmp.pertanian.go.id/blog/post/wirausahamuda-pertanian (2016)

18. Gerakan Pemuda Tani Indonesia, gempita.pertanian.go.id/ (no year)

19. Young Professional in Agricultural Development, Annual Report https://ypard.net/sites/default/files/resources/ypard annual_report_2017_.pdf (2017)

20. J. Leavy, N. Hossain, IDS Working Papers, 2014(439): 1-44. (2014)

21. S.H. Susilowati, Forum Penelitian Agro Ekonomi 34(1): 35-55 (2016)

22. M.S. Reed, A. Graves, N. Dandy, H. Posthumus, K. Hubacek, J. Morris, C. Prell, C.H. Quinn, L.C
Stringer, L. C. J Environ Manag 90(5): 1933-1949 (2009)

23. S. Sinha, Identifying stakeholders in the Ganges Basin to reconcile conservation and competing land uses and processes in the landscape. Proceedings of the International Symposium on River Biodiversity: Ganges-Brahmaputra-Meghna River System (2014)

24. S.H.A. Koop, L. Koetsier, A. Doornhof, O. Reinstra, C.J. Van Leeuwen, S. Brouwer, C. Dieperink, P.P.J. Driessen, Water Resour Manag 17:1-17. (2017)

25. Food and Agricultural Organization, An Introduction to the Basic Concepts of Food Security http://www.fao.org/3/a1936e/al936e00.pdf (2008)

26. Kementerian Keuangan Republik Indonesia, Buku Saku Dana Desa https://www.kemenkeu.go.id/media/6750/bukusaku-dana-desa.pdf (2017)

27. B Birdiani, Dana Desa Dianggap Mampu Melahirkan Petani Baru https://www.gatra.com/detail/news/347832-DanaDesa-Dianggap-Mampu-Lahirkan-Petani-Baru (2018)

28. M. Gewati, Dana Desa untuk Infrastruktur buat Pendapatan Petani Meningkat https://money.kompas.com/read/2019/04/05/113000 826/dana-desa-untuk-infrastruktur-buat-pendapatanpetani-meningkat (2019)

29. S. Tobing, Tak Produktif Lagi Pemerintah Bagikan 978 Ribu Hektare Lahan Hutan https://katadata.co.id/berita/2019/05/07/takproduktif-lagi-pemerintah-bagikan-978-ribuhektare-lahan-hutan (2019)

30. D.A. Muthmainah, Membaca Masa Depan Asuransi Pertanian di Tangan Jasindo https://www.cnnindonesia.com/ekonomi/201711200 93212-84-256780/membaca-masa-depan-asuransipertanian-di-tangan-jasindo (2017)

31. R. Rajagukuguk, Gandeng Jasindo Kementan Luncurkan Aplikasi Asuransi Pertanian https://www.inews.id/finance/makro/gandengjasindo-kementan-luncurkan-aplikasi-asuransipertanian (2019)

32. Konsorsium Pembaruan Agraria, https://kpa.or.id/ (no year)

33. Center for Indonesia's Strategic Development Initiatives, https://cisdi.org/ (no year)

34. J. Feighery, P. Ingram, S. Li, S. Redding, Intersections of Youth \& Food Security (2011)

35. J. Leavy, N. Hossain, IDS Working Papers 2014 (439): 1-44 (2014)

36. Otoritas Jasa Keuangan, Perkembangan Fintech Lending https://www.ojk.go.id/id/kanal/iknb/datadan-statistik/fintech/default.aspx (2019)

37. F. Nangoy, F. Diela, Indonesia's Fintech Lending Boom Exploits Shortfall in Bank Loans https://www.reuters.com/article/us-indonesiafintech/indonesias-fintech-lending-boom-exploitsshortfall-in-bank-loans-idUSKBN1FJ0F4 (2018) 
38. E. Widiyanti, N. Setyowati, D.T. Ardianto, IOP Conf. Ser.: Earth Environ. Sci. 200012060 (2018)

39. V. Ningrum, H. Jogaswara, Engage Youth in Agriculture: Strategies for National Food Sovereignity http://lipi.go.id/publikasi/engageyouth-in-future-agriculture-strategies-for-nationalfood-sovereignty/26948 (2018)

40. Food and Agriculture Organization, Empowering the rural youth in food and agriculture is key to changing the future of migration in Indonesia http://www.fao.org/indonesia/news/detailevents/en/c/1061725/ (2017)

41. I. Setiawan, A. Nugraha, S. Rasiska, IOP Conf. Ser.: Earth Environ. Sci. 306012033 (2019)

42. Y.Y.M. Wuwur, Dana Desa dan Kesejahteraan Petani https://mojok.co/terminal/dana-desa-dankesejahteraan-masyarakat-petani/ (2019) 